\title{
AVALIAÇÃO MICROBIOLÓGICA QUANTITATIVA PARA A PRESENÇA DE COLIFORMES TOTAIS EM CARNE BOVINA MOÍDA E SUA RELAÇÃO COM ASPECTOS DE HIGIENE DAS MÁQUINAS DE MOAGEM DE ESTABELECIMENTOS COMERCIAIS DE UMUARAMA, PR
}

\author{
(QUANTITATIVE MICROBIOLOGICAL EVALUATION FOR THE PRESENCE OF TOTAL \\ COLIFORMS IN GROUND BEEF AND ITS RELATION WITH HYGIENE MILLING MACHINE IN \\ SHOPS UMUARAMA PR)
}

\section{W.A SINHORINI ${ }^{*}$, L.S SILVA ${ }^{2}$, R.R MARTINS ${ }^{3}$, S.R WOSIACK ${ }^{3}$, VIGNOTO V.C ${ }^{4}$, P.M MUNHOZ $^{3}$}

A carne possui caracteres físico-químicos que proporcionam elevado nível de aceitação perante os consumidores, porém é dotada de substratos excelentes para o desenvolvimento microbiano (FELICIO, 1998). Com a manipulação aumentam-se os riscos de contaminação, sendo ainda maior a preocupação quando a carne é previamente fracionada via facas e/ou moedores. Neste contexto, temse que a carne moída contém uma grande superfície de contato, o que a expõe ao maquinário e demais utensílios que por muitas vezes, não são devidamente higienizados - fato este que colabora para a ocorrência de recontaminações (SOUSA, 2006). Objetivou-se verificar a qualidade higiênico-sanitária da carne bovina moída comercializada em 10 pontos do comércio do município de Umuarama - PR e sua relação com aspectos de higiene das máquinas de moagem. Para tanto, foram coletadas 40 amostras, acondicionadas e transportadas para processamento no Laboratório de Microbiologia da UEM, Campus Umuarama - PR. Estas foram diluídas em água peptonada 0,1\%, a partir da qual obtiveram-se diluições decimais até $10^{-3}$, sendo $1 \mathrm{~mL}$ de cada inóculo obtido semeado em placas Petrifilm ${ }^{\circledR} 3 \mathrm{M}$ (MUNHOZ, 2007) e então incubadas a $35^{\circ} \mathrm{C} \pm 1{ }^{\circ} \mathrm{C}$ por $24 \pm 2$ horas, para contagem de coliformes totais (microrganismos indicadores de segurança alimentar) (Método Oficial AOAC 991.14). Também aplicou-se um questionário (checklist) individualmente aos 53 manipuladores de carne que mostraram-se diretamente envolvidos com essas amostras. O produto deste trabalho foi concluído através da correlação efetuada entre questionário e dados microbiológicos, demonstrando de forma clara a presença de microrganismos na carne quando associada à frequiência e métodos de higienização constatados dos equipamentos utilizados. Assim, observou-se que a carne moída comercializada no município de Umuarama, PR, ainda revela índices elevados de microrganismos em decorrência da baixa higienização dos instrumentos/aparelhos que entram em contato com o alimento, e também decorrente da falta de asseio de alguns dos profissionais envolvidos, desfavorecendo o consumidor. 